\title{
The Art of Talc Flotation for Different Industrial Applications
}

\author{
Tawfik Refaat Boulos, Suzan Sami Ibrahim, Ahmed Yehia \\ Central Metallurgical Research and Development Institute (CMRDI), Cairo, Egypt \\ Email: trboulos83@gmail.com, suzansibrahim@gmail.com, ahmedyehia130@yahoo.com
}

Received 18 April 2016; accepted 20 May 2016; published 23 May 2016

Copyright (C) 2016 by authors and Scientific Research Publishing Inc.

This work is licensed under the Creative Commons Attribution International License (CC BY). http://creativecommons.org/licenses/by/4.0/

(c) (i) 0pen Access

\section{Abstract}

Talc has found a steadily increasing number of uses such as cosmetics, steatite and cordierite ceramics, for pitch control in the paper industry and as a reinforcing filler in rubber, etc. In this research, the amenability of some Egyptian carboniferous finely disseminated talc ores to beneficiation by flotation was investigated on laboratory scale. The original talc sample is characterized by low MgO content (25.40\%), low $\mathrm{SiO}_{2}$ (45.71\%), high CaO content (6.32\%) and high L.0.I. (11.35\%), indicating its low grade. Attrition scrubbing of the crushed ores was found to be an unconventional process, not only for fine talc production, but also for proper separation of the harder carbonaceous gangue. Talc pre-concentrates, less than $0.074 \mu \mathrm{m}$, were prepared by attrition scrubbing in the laboratory having $\mathbf{8 . 4 0} \%$ L.O.I. with a yield reaching $\mathbf{7 4 . 7 0 \%}$. Cleaner talc concentrate with L.O.I. content averaging $6.70 \%$ was obtained by flotation in the presence of Aerofroth 71 with a yield reaching $64.71 \%$. This was relatively improved by the use of a selective (quaternary amine) talc collector and in presence of a selective carbonate depressant (soda ash). Flotation of the fine ground talc (less than $22 \mu \mathrm{m}$ ) produced a talc concentrate assaying $6.90 \%$ L.0.I. with a yield recovery of $\mathbf{6 2 . 9 1 \%}$. However, different talc concentrates obtained by just natural floatability or by the use of small dose of Aerofroth 71, or by the application of quaternary amine in presence of carbonate depressant, satisfy the requirement of paper coating, ceramics production, functional filler, and pharmaceuticals applications. Tailings could also be used in carpets, roofs, and tiles production industries.

\section{Keywords}

Flotation, Depression, Attrition Scrubbing, Carbonate Separation

\section{Introduction}

The basic concept of native floatability of a mineral is that a naturally hydrophobic surface results when clea- 
vage or fracture occurs between crystal layers which are held together by weak residual bonds-van der Waals forces. It is recognized that the crystalline structure is one of the main factors that determines the wettability of layered silicate minerals such as talc. Talc is a hydrous magnesium silicate, $\mathrm{Mg}_{3} \mathrm{Si}_{4} \mathrm{O}_{10}(\mathrm{OH})_{2}$, which is related to the sheet structure of the phyllosilicate (Yehia and Al Wakeel, 2000 [1]). However, natural floatability of talc is closely related to its three-layer sheet crystal structure (Fuerstenau et al., 2003 [2] and Fuerstenau et al., 2007 [3]). Positive charge of magnesium layer is compensated from two sides by silicon tetrahedral layers creating the lack of surface polarization responsible for its natural hydrophobicity.

Talc is considered as anisotropic mineral, which when broken, two types of surfaces are formed, one resulting from the easily broken layers and the other resulting from the rupture of ionic bonds within these layers (Ivan et al., 2013 [4]). The former are termed as "faces", holding together by weak van der Waals forces, which are hydrophobic and consist of inert - $\mathrm{Si}-\mathrm{O}-\mathrm{Si}-$ groups. The latter are termed as "edges", which are hydrophilic, consisting of $\mathrm{SiOH}$ and $\mathrm{MgOH}$ groups, and are held together by ionic bond. However, the edges which are created by rupturing of the covalent bonds are spontaneously reacting with water to form oxidic sites, for example, $\mathrm{SiO}^{-}$ that is hydrophilic. On the other hand, the rupture of talc crystals along the faces generates non-polar surfaces, which are characterized by a low energy (El-Midany and Ibrahim, 2010 [5]; Mierczynska and Beattie, 2013 [6]). This allows talc to exhibit an inherent hydrophobicity, which is the basis of the separation of talc, by flotation, from other ore constituents in mineral industry. However, the heterogeneous character of talc surface particles has a particular importance in flotation. The face/edge relationship, which depends on the particle size, determines the natural floatability of this mineral (Mierczynska and Beattie, 2013 [6]). Besides, the solution pH affects the talc floatability. In acidic and alkaline solution, water molecules would hydrate the negatively charged sites $\left(\mathrm{SiO}^{-}\right)$on the edges and hence, the talc surface would be more hydrophilic (Yehia and Al Wakeel, 2000 [1]). At neutral $\mathrm{pH}$, talc surface has a weak affinity for water molecules and air bubbles readily displace any weakly adsorbed water on the uncharged surface.

The size of an individual talc platelet (a few thousand elementary sheets) can vary from approximately $1 \mathrm{mi}-$ cron to over 100 microns depending on the conditions of formation of the deposit. It is this individual platelet size that determines a talc's lamellarity. A highly lamellar talc will have large individual platelets whereas a microcrystalline talc will have small platelets. The elementary sheets are stacked on top of one another, like flaky pastry, and because the binding forces (Van der Waal's forces) linking one elementary sheet to its neighbors are very weak, the platelets slide apart at the slightest touch, giving talc its characteristic softness.

Different methods and approaches were investigated by researchers worldwide for the processing of talccarbonate ores with different proportions of talc, magnesite and dolomite (Houot et al., 1995 [7]; Marabini et al., 1996 [8]; Weber, 1998 [9]; Karlsen et al., 2000 [10]; Derco and Memeth, 2002 [11]; Ahmed et al., 2011 [12]), and CANMET of Canada carried out an intensive R \& D work on so many talc and pyrophyllite varieties by applying a wide array of frothers and collectors (Andrews, 1994 [13]; Wyman, 1973 [14]).

Talc occurs in the form of veins or lenses in many localities in South and Central Eastern Desert of Egypt (EGSMA, 1991; MQA, 2004). Generally, talc is obtained by either open pit or underground mining. The cost of overburden removal in open pit mining is a major factor in talc mining and waste rock to ore ratios of 40:1 are not uncommon. Processing of low grade varieties is becoming unequivocal and few studies are carried out, on a laboratory scale, to separate both carbonate and iron oxide gangue minerals (Yousef et al., 1995 [15]; El-Wakeel, 1996 [16]; Ibrahim, 2003 [17]; Selim, A.Q., Ibrahim, S.S. and El Manawi, A.W., 2005 [18]; Hassan et al., 2007 [19]). This article is a step on the same road for the maximum utilization of the Egyptian talc deposits.

\section{Material and Methods}

A technological talc sample, about five tonnes, representing Bir Meseh, south of Shalatin locality of the Eastern Desert of Egypt, was kindly supplied by the National Service Sector, Ministry of Defense for investigation. Geologically, the talc deposits of Shalatine locality occur as large fragments of variable sizes enclosed in mafic-ultramafic matrix, or occur as lenses and pockets associating metasediments (Selim et al., 2005). The two associations of talc deposits are restricted to NW-SE shear zones. The rocks within the shear zones are highly brecciated, deformed and extensively altered. The delivered sample represents the previous mentioned genetic types of talc.

Ore characterization was carried out by overall analyses, using XRF model Axios advanced-panalytical and ore microscopy. Attrition scrubbing of the $-11 \mathrm{~mm}$ crushed ores was carried out in the laboratory using the 
"Denver D12" flotation cell. In this process, the attritioned product was screened on a $74 \mu \mathrm{m}$ screen and both oversize and undersize fractions were weighed and analyzed for loss on ignition, L.O.I. This latter size fraction was directed to further fine grinding to improve the degree of liberation of minerals, i.e. until $100 \%$ less than 22 $\mu \mathrm{m}$. Flotation of this superfine feed was conducted in the same conventional subaeration flotation cell. Aerofroth 71 was used as a frother for talc whereas soda ash was tested as selective depressant of carbonate. In the meantime, quaternary amine was employed in the laboratory as a selective collector for talc.

\section{Results and Discussion}

\subsection{Sample Characterization}

Complete chemical analysis of the talc sample, supported with the results of the XRD (Figure 1), indicates that it is high in undesirable ingredients, e.g. iron oxides and $\mathrm{CaO}$ (Table 1). It is characterized by low MgO content (25.40\%), low $\mathrm{SiO}_{2}$ (45.71\%), high $\mathrm{CaO}$ content (6.32\%) and high L.O.I. (11.35\%) indicating its low grade (Table 1).

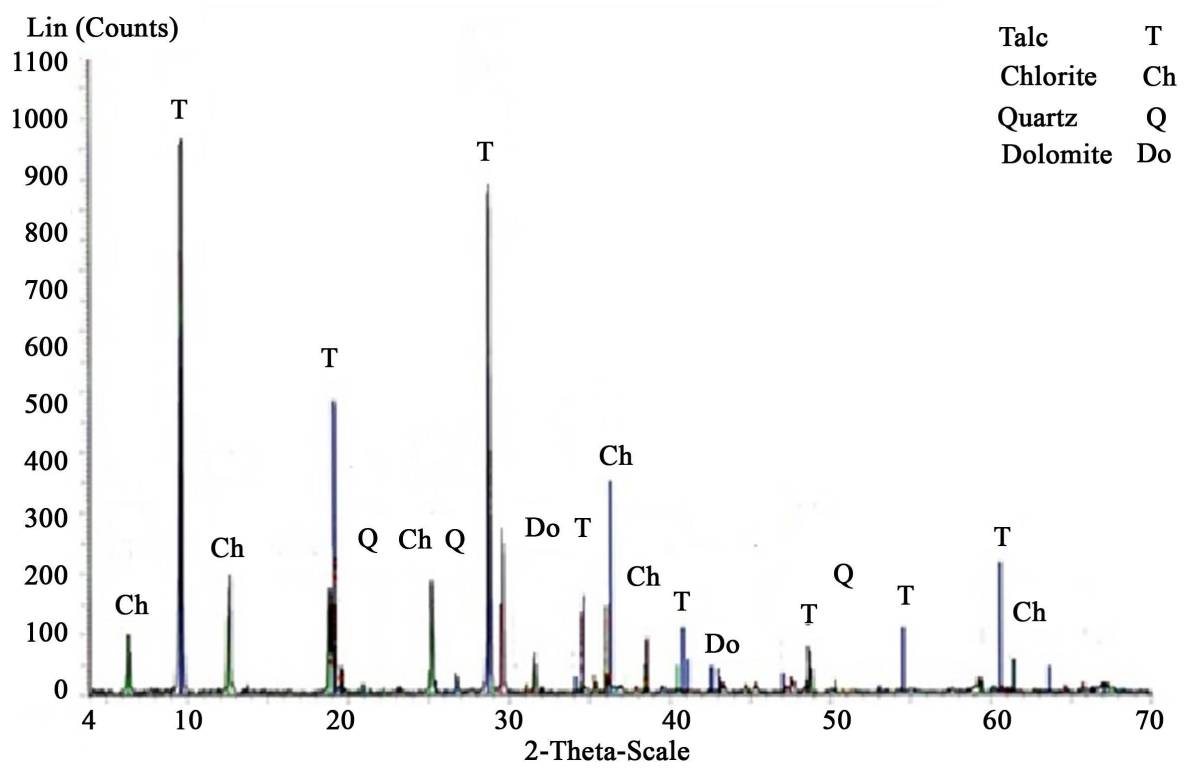

Figure 1. XRD patterns of original Shalatin talc sample.

Table 1. Complete chemical analysis of original Shalatin talc sample.

\begin{tabular}{cc}
\hline Constituent & Sample \\
$\mathrm{SiO}_{2}$ & 45.71 \\
$\mathrm{TiO}_{2}$ & 0.11 \\
$\mathrm{Al}_{2} \mathrm{O}_{3}$ & 3.35 \\
$\mathrm{Fe}_{2} \mathrm{O}_{3}$ & 1.15 \\
$\mathrm{MnO}$ & 0.05 \\
$\mathrm{MgO}$ & 25.40 \\
$\mathrm{CaO}$ & 6.32 \\
$\mathrm{Na}_{2} \mathrm{O}$ & $<0.01$ \\
$\mathrm{~K}_{2} \mathrm{O}$ & $<0.01$ \\
$\mathrm{P}_{2} \mathrm{O}_{5}$ & 0.05 \\
$\mathrm{Cl}$ & $<0.01$ \\
$\mathrm{SO}_{3}$ & $<0.01$ \\
$\mathrm{~L} . \mathrm{O} . \mathrm{I}$. & 11.35 \\
\hline
\end{tabular}


Mineralogical investigation by XRD, using EVA software, shows that the main sample constitution is talc (48\%), dolomite (27\%), calcite (6\%), chlorite, serpentine, sphene and iron oxides (19\%) (Figure 1). Petrography study of the talc sample reveals that the talc sample includes four main lithological groups: steatite group, talccarbonate group, talc-chlorite group, and ferruginated talc group (Plate 1). This study shows also that the talc sample is characterized by fine-grained talc fragments with apple green color, enclosed in white color harder carbonate matrix.

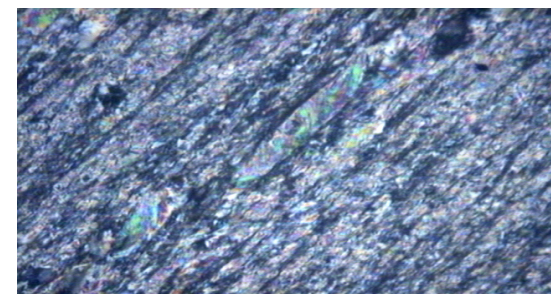

(a)

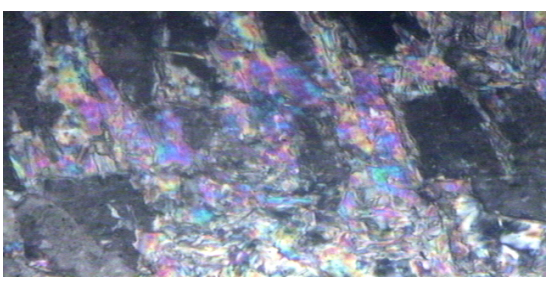

(c)

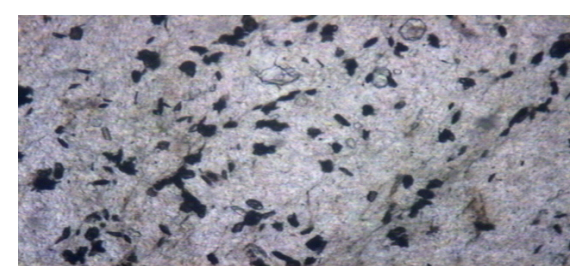

(e)

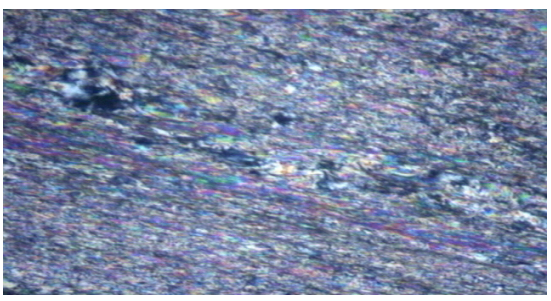

(b)

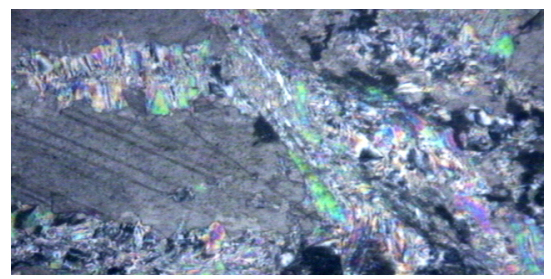

(d)

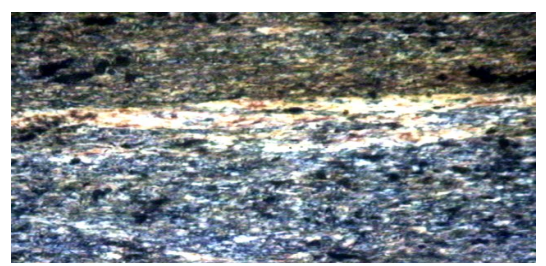

(f)

Plate 1. Petrographic investigation of Shalatin talc sample.

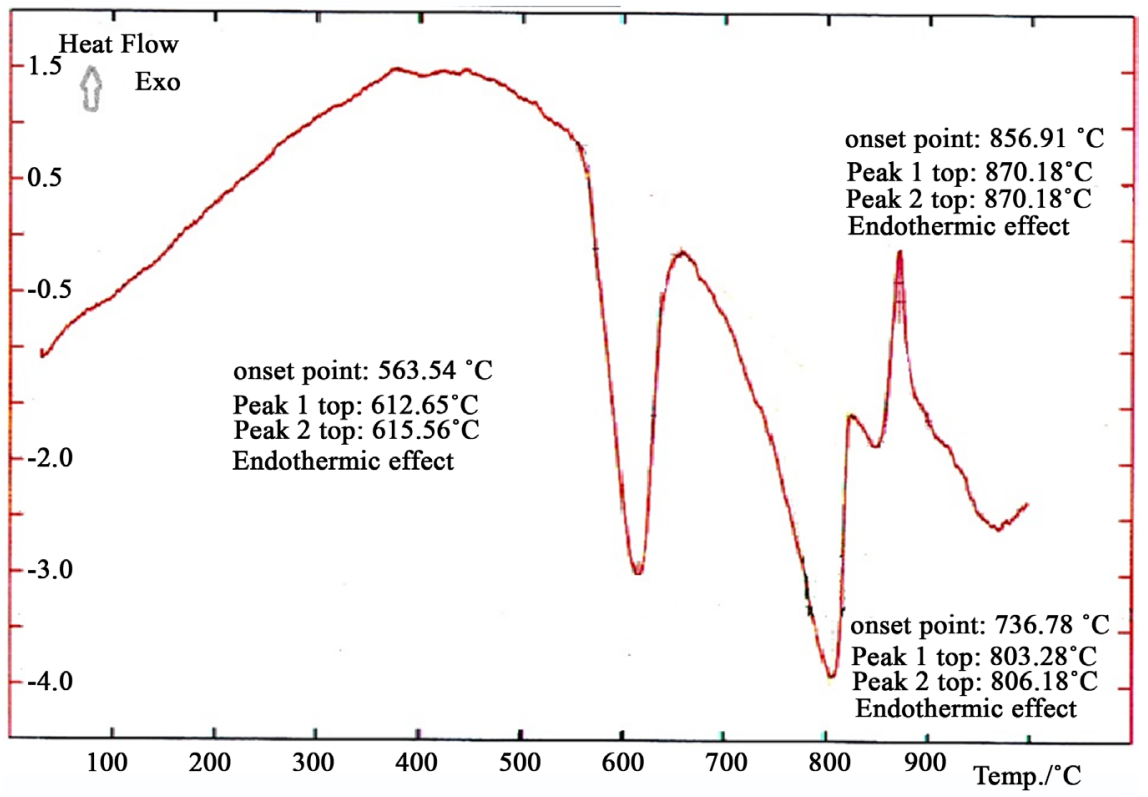

Figure 2. Thermal analysis of original Shalatin talc sample. 
On the other hand, Figure 2 illustrates the thermal analysis of the talc sample. Despite the single endothermic peak characteristic of talc at about $950^{\circ} \mathrm{C}-1000^{\circ} \mathrm{C}$, the sample demonstrates a sharp endothermic reaction peak at $600^{\circ} \mathrm{C}$ associated with an exothermic reaction between $800^{\circ} \mathrm{C}$ and $900^{\circ} \mathrm{C}$ which is related to dolomite mineral (Figure 2). This corroborates with both the high L.O.I. and $\mathrm{CaO}$ contents. Chlorite presence was also confirmed by both XRD and DTA analyses.

High grade steatite, the only mineral shown is talc (Medium grained talc occurs in narrow shear zone parallel to the main foliation planes), B-Photomicrograph of exclusively sheared talc (Notice, the shear foliations and the offset in coarse talc flake "Tc" (Crossed Nicols), C-Coarse flakes of talc "Tc" attacking coarse carbonate crystals "Ca" and corroding it, talc-carbonate rock (Crossed Nicols), D-Photomicrograph shows growth of well developed talc flakes at the expense of mega calcite crystal (Crossed Nicols), E-Microscopic banded structure in the talc-chlorite rock, the upper band rich in opaques and iron staining, the middle band is mainly talc, the lower band consists of talc and chlorite intergrowth (Crossed Nicols), and F-Medium-grained talc contains large amount of opaques (Plane Polarized light).

\subsection{Attrition Scrubbing of the Crushed Ores}

This technique was suggested as a substitute of the conventional ball or rod milling in talc beneficiation plants by taking advantage of the friable nature of talc, being at the top of Moh's scale. The objective of this process was to achieve preconcentration of talc by fractional grinding from the harder carbonate impurities. Optimization of the process in the laboratory including verification of the attrition speed, attrition time and pulp density are shown in Figures 3-5.

\section{A. Effect of Changing Motor Speed}

Figure 3 illustrates the effect of varying the attritioning motor speed on both the yield and grade of both the under- and oversize products at 50\% solid and an optimum attritioning time of $60 \mathrm{~min}$. Evidently, the substantial increase in the process recovery from $69.3 \%$ at a motor speed of $1500 \mathrm{rpm}$ to $79.5 \%$ at a speed of $2100 \mathrm{rpm}$ was accompanied by an incremental increase in the preconcentrate \% L.O.I.

\section{B. Effect of Changing Attritioning Time}

At 50\% solid, $1500 \mathrm{rpm}$ motor speed and $15 \mathrm{~min}$. attritioning time about $50 \%$ by weight of the crushed rock reports to the -200 mesh size with a L.O.I. reaching $8.2 \%$ as compared with $14.9 \%$ in the oversize product. After $60 \mathrm{~min}$. attritioning time, the weight percent of the talc preconcentrate, -200 mesh, reaches about $69.3 \%$ without a pronounced decrease in its grade (Figure 4). This technique, which sounds unconventional in talc processing

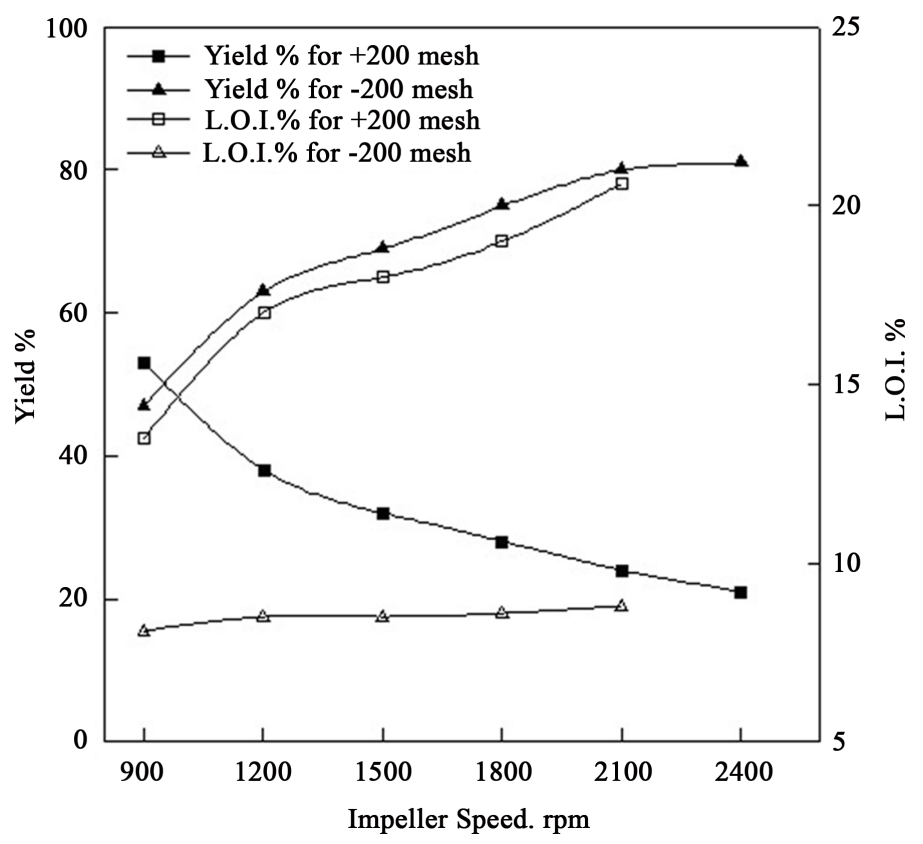

Figure 3. Effect of varying impeller speed on attrition scrubbing of talc sample. 


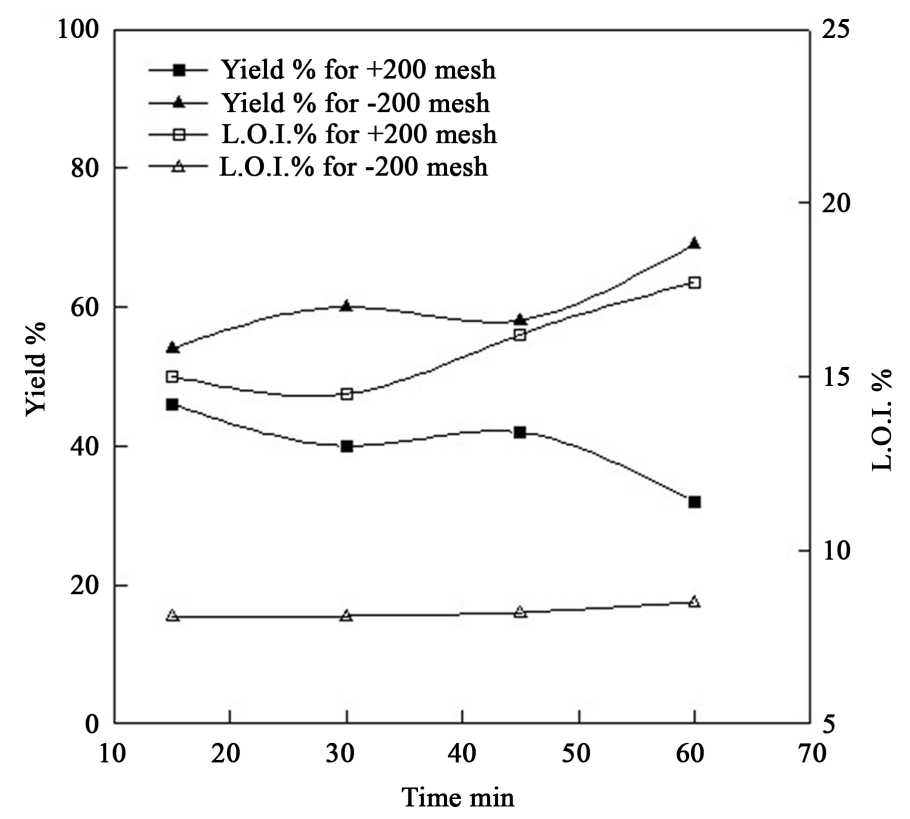

Figure 4. Effect of attrition time on talc sample (at 50\% solid, $1500 \mathrm{rpm}$ ).

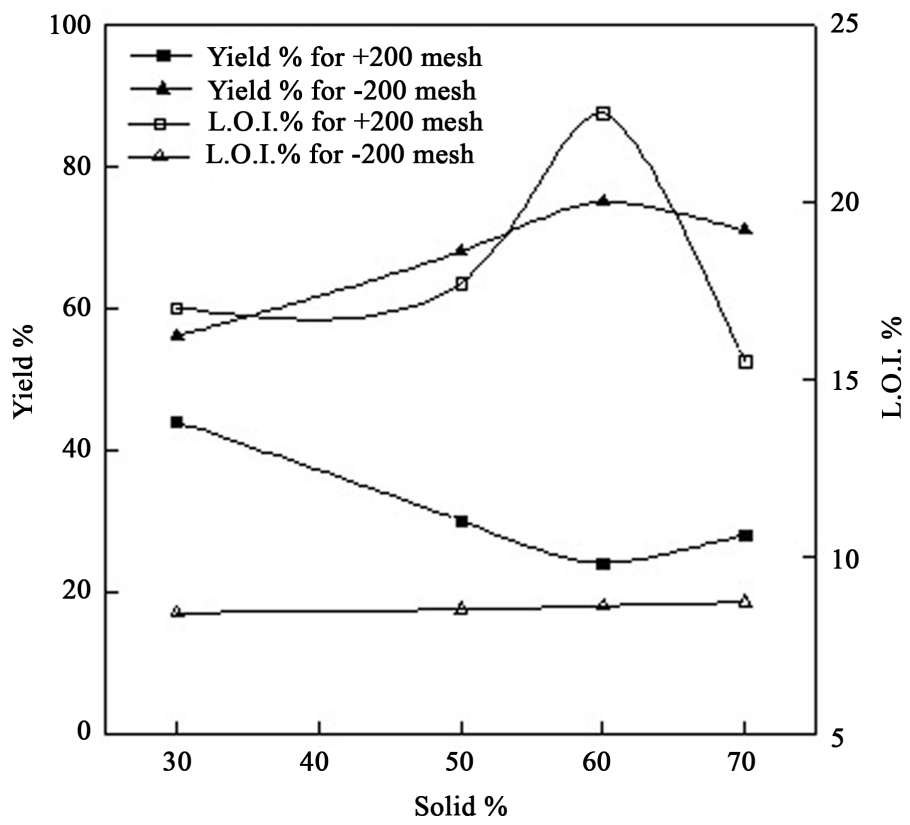

Figure 5. Effect of varying solid/liquid ratio on attrition scrubbing of talc sample (at $1500 \mathrm{rpm}, 60 \mathrm{~min}$ ).

technology, looks encouraging in rejecting about 48\% of the associating hard carbonaceous impurities (assaying 17.6\% L.O.I.) from Shalatin talc sample.

\section{Effect of Changing Pulp Density}

Figure 5 shows that increasing the\% solid in the pulp from $50 \%$ to $70 \%$ at a motor speed of $1500 \mathrm{rpm}$ and 60 min. attritioning time, the \% yield of the talc preconcentrate increases to an optimum of $74.7 \%$ at $60 \%$ solid with a L.O.I. of $8.5 \%$. But the process becomes, almost, impractical by increasing the\% solid in the pulp more than that due to consolidation. Therefore, a talc preconcentrate having about 8.4\% L.O.I. was obtained by attrition scrubbing of the $-11 \mathrm{~mm}$ crushed ore at $60 \%$ solid, $1500 \mathrm{rpm}$ motor speed and $60 \mathrm{~min}$. attritioning time, at a yield of about $74.7 \%$. 
Carbonate Separation by Flotation

Although the talc surface has a net hydrophobic character, two additional factors must be considered in order to fully appreciate its flotation chemistry. First, there may be a significant number of hydrophilic sites on the talc surface. The second factor is that during size reduction other planes of the crystal may be exposed which do not have a net hydrophobic character. However, due to the anisotropic structure of talc, three types of surfaces will be produced: hydrophobic (faces), partially hydrophobic (faces and edges) and hydrophilic (edges). Accordingly, flotation of talc pre-concentrate for separation of carbonate was studied in the laboratory within three complementary routes as follows:

a-Natural floatability of talc will be achieved for hydrophobic surfaces (faces).

b-Enhanced natural floatability of talc by using a frother for partially hydrophobic surfaces.

c-Conventional talc flotation using a collector (quaternary ammonium salt) for hydrophilic surfaces (edges) in presence of selective carbonate depressant (soda ash).

\section{Natural Floatability of Talc}

The effect of changing the impeller speed on the natural floatability of talc while changing the pulp $\mathrm{pH}$ showed modest recovery of the process and its independence of $\mathrm{pH}$ (Table 2). This results in a concentrate assaying about $6 \%$ L.O.I. with a recovery of about 32\% at an impeller speed of $1200 \mathrm{rpm}$.

\section{Addition of Frother for Partially Hydrophobic Surfaces}

Talc mineral, as a predominantly hydrophobic solid, may still possess a number of polar sites. When a meniscus recedes from such a surface it leaves few (if any) isolated water molecules on non-polar sites but clusters of them are around polar sites. This concept explains why talc mineral needs only a fraction of a monolayer of frother to render it floatable. Floatation results as a function of frother concentration at $\mathrm{pH} 8$ (the optimum $\mathrm{pH}$ of the natural floatability) are shown in Table 3 . By adding Aerofroth 71, the recovery increases significantly with increasing frother concentration but this happens on the prejudice of the grade of the concentrate. By using 300 $\mathrm{g} / \mathrm{t}$ of the frother a talc concentrate assaying 6.7\% L.O.I. was obtained with a yield recovery of $64.71 \%$.

\section{Talc Flotation using a Collector for Hydrophilic Surfaces}

When using quaternary amine as a selective talc collector, the grade of concentrate is not encouraging (Table 4). Talc concentrate assaying $7.78 \%$ L.O.I. was obtained with a yield recovery of $86.88 \%$. But in the presence of soda ash as a selective carbonate depressant, flotation indices relatively improve (Table 5). Cleaner talc concentrate assaying 6.5\% L.O.I. but with a lower recovery of $56.35 \%$ was obtained using $0.5 \mathrm{~kg} / \mathrm{t}$ of soda ash and 0.2 $\mathrm{kg} / \mathrm{t}$ quaternary amine at natural $\mathrm{pH}$.

\section{Stepwise Flotation of the $\mathbf{- 7 4} \boldsymbol{\mu m}$ Size Fraction}

According to the above results, stepwise flotation of the $-74 \mu \mathrm{m}$ size fraction was conducted including natural Table 2. Results of impeller speed of the attrition process on talc sample ( $-74 \mathrm{um}$ ) natural floatability.

\begin{tabular}{|c|c|c|c|c|}
\hline $\mathrm{pH}$ & Impeller speed, rpm & Product & $\% \mathrm{Wt}$. & \% L.O.I. \\
\hline \multirow{6}{*}{8} & \multirow{3}{*}{900} & Conc. & 25.61 & 5.77 \\
\hline & & Tail & 74.39 & 9.04 \\
\hline & & Total & 100 & 8.20 \\
\hline & \multirow{3}{*}{1200} & Conc. & 32.26 & 6.00 \\
\hline & & Tail & 67.74 & 9.25 \\
\hline & & Total & 100 & 8.20 \\
\hline \multirow{6}{*}{12} & \multirow{3}{*}{900} & Conc. & 25.96 & 5.93 \\
\hline & & Tail & 74.04 & 9.00 \\
\hline & & Total & 100 & 8.20 \\
\hline & \multirow{3}{*}{1200} & Conc. & 31.12 & 5.99 \\
\hline & & Tail & 68.88 & 9.20 \\
\hline & & Conc. & 100 & 8.20 \\
\hline
\end{tabular}


Table 3. Effect of Aerofroth 71 addition on talc sample (-74 um) floatability.

\begin{tabular}{|c|c|c|c|}
\hline Dose of frother, $\mathrm{g} / \mathrm{t}$ & Product & $\% \mathrm{Wt}$. & \% L.O.I. \\
\hline \multirow{3}{*}{100} & Conc. & 43.37 & 5.92 \\
\hline & Tail & 56.63 & 9.95 \\
\hline & Total & 100 & 8.20 \\
\hline \multirow{3}{*}{200} & Conc. & 52.87 & 6.30 \\
\hline & Tail & 47.13 & 10.33 \\
\hline & Total & 100 & 8.20 \\
\hline \multirow{3}{*}{300} & Conc. & 64.71 & 6.70 \\
\hline & Tail & 35.29 & 10.95 \\
\hline & Total & 100 & 8.20 \\
\hline \multirow{3}{*}{500} & Conc. & 60.27 & 6.60 \\
\hline & Tail & 39.73 & 10.63 \\
\hline & Total & 100 & 8.20 \\
\hline
\end{tabular}

Table 4. Flotation using quaternary ammonium salt as a collector.

\begin{tabular}{ccccc}
\hline $\mathrm{pH}$ & Dose, $\mathrm{kg} / \mathrm{t}$ & Product & \% Wt. & \% L.O.I. \\
\hline & 0.2 & Conc. 1 & 32.31 & 6.98 \\
7 & 0.2 & Conc. 2 & 30.44 & 8.17 \\
& 0.2 & Conc. 3 & 25.60 & 11.69 \\
& & Tail & 11.65 & 8.30 \\
& & Total & 100 & 6.56 \\
& 0.2 & Conc.1 & 21.60 & 7.80 \\
& 0.2 & Conc.2 & 32.80 & 8.51 \\
\hline
\end{tabular}

Table 5. Effect of using soda ash for carbonate depressants in talc flotation using quaternary ammonium salt as a collector.

\begin{tabular}{cccc}
\hline & & Soda ash & \\
\cline { 2 - 4 } Dose Kg/t & Product & \% Wt. & \% L.O.I. \\
\hline \multirow{2}{*}{0.25} & Conc. & 66.32 & 6.8 \\
& Tail & 33.68 & 13.01 \\
& Total & 100 & 8.88 \\
& Conc. & 56.35 & 6.53 \\
\hline
\end{tabular}


floatability of talc, addition of frother, collector and depressant. Table 6 shows that three concentrates of talc were produced assaying 5.83\%, 6.33\% and 7.21\% L.O.I. with yield recoveries of $24.22 \%$, $23.17 \%$ and $7.32 \%$, respectively.

\section{Flotation of the $-22 \mu \mathrm{m}$ Size Fraction}

Further grinding of the flotation feed sample was decided to improve these results. Table 7 shows the results of a step flotation of the $-22 \mu \mathrm{m}$ superfine talc pre-concentrate. Using the same conventional type "Denver D 12" flotation cell, this latter superfine feed responded easily to natural floatability without the use of a collector where a first concentrate was obtained assaying $6.6 \%$ L.O.I. with a yield recovery of $28.48 \%$. By using soda ash and frother, second concentrate assaying 7.60\% L.O.I. was obtained with a yield recovery of 34.43\% (Table 7). The needle-like crystals of talc concentrate is shown in Figure 6.

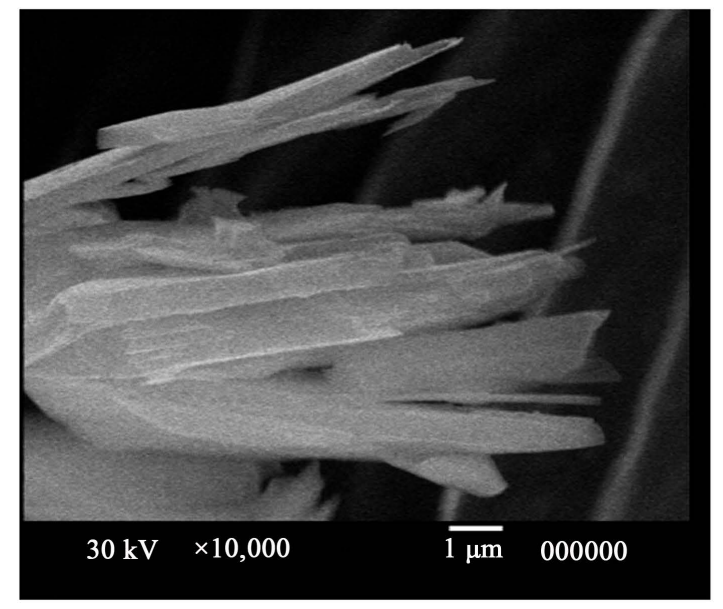

(a)

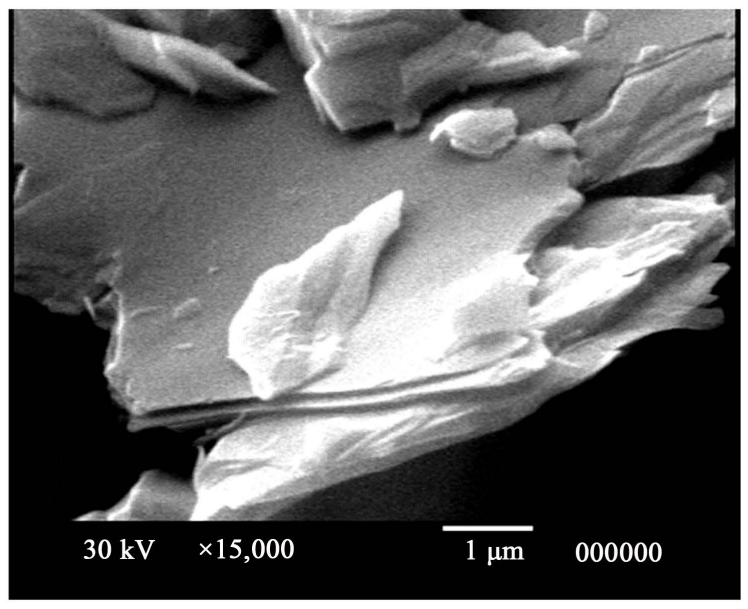

(b)

Figure 6. SEM photographs of Shalatine talc concentrate. (a) Needle-like crystals of talc; (b) Talc blades arranged in sheet structure.

Table 6. Step flotation results of the $-74 \mu \mathrm{m}$ scrubbed talc sample.

\begin{tabular}{|c|c|c|c|}
\hline Operation & Product & $\% \mathrm{Wt}$. & \% L.O.I. \\
\hline Natural floatability & Conc.1 & 24.22 & 5.83 \\
\hline Addition of a frother & Conc. 2 & 23.17 & 6.33 \\
\hline \multirow[t]{2}{*}{ Addition of a collector in presence of soda ash } & Conc.3 & 7.32 & 7.21 \\
\hline & Tailing & 14.59 & 15.79 \\
\hline \multirow[t]{3}{*}{ Attrition scrubbing } & +200 mesh & 30.7 & 18.96 \\
\hline & Total & 100 & 11.53 \\
\hline & Head & 100 & 11.53 \\
\hline
\end{tabular}

Table 7. Stepwise flotation results of the $-22 \mu \mathrm{m}$ scrubbed talc sample.

\begin{tabular}{|c|c|c|c|}
\hline Operation & Product & $\% \mathrm{Wt}$. & \% L.O.I. \\
\hline Natural flotation & Conc. 1 & 28.48 & 6.60 \\
\hline \multirow[t]{2}{*}{ Addition of a depressant and a frother } & Conc.2 & 34.43 & 7.60 \\
\hline & Tailing & 6.39 & 15.59 \\
\hline \multirow[t]{3}{*}{ Attrition scrubbing } & +200 mesh & 30.70 & 18.96 \\
\hline & Total & 100 & 11.31 \\
\hline & Head & 100 & 11.53 \\
\hline
\end{tabular}




\section{Conclusion}

Attrition scrubbing of the $-11 \mathrm{~mm}$ crushed talc sample was proved to be an unconventional process for separation of the harder carbonate gangue minerals in the $+74 \mu \mathrm{m}$ oversize product and in the production of talc superfine $-22 \mu \mathrm{m}$ as well. Minimization of the carbonate content of talc pre-concentrate by multistage flotation was optimized in the laboratory through natural floatability of the talc and application of a selective carbonate depressant. Fine grinding of the talc to less than $22 \mu \mathrm{m}$ was imperative to improve the recovery of the process. Flotation of such superfine talc using the conventional "Denver" sub-aeration flotation cell proceeded well with the addition of frother and carbonate depressant without the addition of talc collector. A concentrate assaying $54 \% \mathrm{SiO}_{2}, 33.56 \% \mathrm{MgO}, 1 \% \mathrm{Fe}_{2} \mathrm{O}_{3}, 1.44 \% \mathrm{CaO}$, and $6.9 \%$ L.O.I. with a recovery of $62.91 \%$ was obtained. This satisfies the world market requirements for plastics, paints, ceramics and paper also since its brightness is 89.0 and its oil absorption is 20. Evaluation of other flotation products indicates their suitability for both carpets and roofing purposes.

\section{References}

[1] Yehia, A. and Al-Wakeel, M.I. (2000) Talc Separation from Talc-Carbonate Ore to Be Suitable for Different Industrial Applications. Mineral Engineering, 13, 111-116. http://dx.doi.org/10.1016/S0892-6875(99)00154-5

[2] Fuerstenau, M.C., Jameson, G. and Noor, R. (2007) Froth Flotation: A Centaury of Innovation. Society for Mining, Metallurgy, and Exploration, Inc., Littleton, CO, USA, 8975.

[3] Fuerstenau, D.W. and Huang, P. (2003) Interfacial Phenomena Involved in Talc Flotation and Depression. XXII International Mineral Processing Congress, South Africa, 28 September-3 October 2003, 1034-1043.

[4] Ivan, B., Fridrich, Z. and Miroslav, Z. (2013) Collectorless Flotation of Talc-Magnesite Ore with Respect to Particle Size. Acta Montanistica Slovaca, 18, 198-205.

[5] El-Midany, A.A. and Ibrahim, S.S. (2010) The Effect of Mineral Surface Nature on Improving the Mechanical Properties of Filled-Polypropylene Composites. Polymer Bulletin, 64, 387. http://dx.doi.org/10.1007/s00289-009-0209-x

[6] Mierczynska, V.A. and Beattie, D.A. (2013) The Effect of Impurities and Cleavage Characteristics on Talc Hydrophobicity and Polymer Adsorption. International Journal of Mineral Processing, 118, 34-42.

[7] Houot, R., Joussemet, R., Yong, S. and Baeza, R. (1995) Beneficiation of Talc Products. 1st UBC-McGill Bi-Annual International Symposium of Fundamentals in Mineral Processing, Vancouver, BC, Canada, $20-24$ August 1995, 378-384.

[8] Marabini, A.M., Belardi, G. and Spaziani, E. (1996) Beneficiation of Talc from Valmalenco Mine. Mines and Quarries Authority, MQA, Internal Report No. 61.

[9] Weber, K.E. (1998) Beneficiated Talc. U.S. Patent 111-98.

[10] Karlsen, T.A., Rian, E. and Olesen, O. (2000) Overview of Talc Resources in the Altermark Talc Province, Northern Norway, and Possible Uses of the Talc Ore. NGU-BULL, 436, 93.

[11] Derco, J. and Nemeth, Z. (2002) Obtaining of High Quality Talc from Talcose Rocks: A Case Study from the Sinec and Kokava Deposits (Slovakia). Boletim Paranaense de Geociências, No. 50, 119-130.

[12] Ahmed, M.M., Ibrahim, G.A. and Hassan, M.M.A. (2011) Beneficiation of Talc Ore. In: Dar, I.A. and Dar, M.A., Eds., Earth and Environmental Sciences, Chap. 11, India, 241-272.

[13] Andrews, P.R.A. (1994) Beneficiation of Canadian Talc and Pyrophyllite Ore: A Review of Processing Studies at CANMET. CIM Bulletin, 87, 64-68.

[14] Wyman, R.A. (1973) Concentration Tails of a Talc Sample from British Columbia. CANMET, Energy, Mines and Resources, Canada.

[15] Yousef, M.A., Yehia, A. and Ibrahim, S.S. (1995) Beneficiation of Egyptian Talc-Magnesite Ore for the Production of Some Types of Basic Refractories. Modeling, Measurement, and Control, 47, 5-20.

[16] Al Wakeel, M. (1996) Beneficiation of Some Egyptian Talc_Carbonate Rocks. PhD Thesis, Ain Shams University, Cairo, Egypt.

[17] Ibrahim, S.S. (2003) Influence of Talc Characteristics as a Functional Filler on Physico-Mechanical Properties of Filled-PP Composites. Ore Dressing Journal, 5, No. 8.

[18] Selim, A.Q., Ibrahim, S.S. and El Manawi, A.W. (2005) Mineralogical Evaluation and Upgrading of Shalatine Talc for Different Industrial Applications. The 8th International Conference on Geology of the Arab World, Cairo, March 2005, 21-32.

[19] Hassan, M.M.A., Ahmed, M.M. and Ibrahim, G.A. (2007) Improvement of Egyptian Talc Quality for Industrial Uses by Flotation Process and Leaching. International Journal of Mineral Processing, 83, 132-145. 